2. Афанасьева И.В., Белова Д.А. Пути реформирования института мирового соглашения в делах о банкротстве // Арбитражный и гражданский процесс. - 2001. - №4. - С. 18-19.

3. Гринь Е.А., Иванчик И.С. Мировое соглашение при процедуре банкротства // В сборнике: Государство, право и общество: вопросы теории и практики. Материалы второй Всероссийской научно-практической конференции. Отв. редактор В.И. Скрябин. - 2020. - С. 91-99.

4. Гринь Е.А., Калинина П.И. Проблемы заключения и реализации третейских соглашений // Аграрное и земельное право. 2019. № 9 (177). С. 148-151.

5. Гуева, А. В. Особенности заключения мирового соглашения как разновидности процедур несостоятельности (банкротства) // Современная юриспруденция: актуальные вопросы, достижения и инновации: Сборник статей II Международной научно-практической конференции "Наука и Просвещение". - 2017. - С. $228-230$.

6. Минетдинова, В. Д. Преимущества заключения мирового соглашения перед другими процедурами при банкротстве // Международный журнал гуманитарных и естественных наук. - 2021. - № 4-4(55). - С. 69-71.

\title{
Якименко К.С. \\ Правовая природа транснациональных корпораций как субъектов международного частного права
}

ФГБОУ ВО «Кубанский государственный аграрный университет имени И.Т. Трубилина»

(Россия, Краснодар)

doi: 10.18411/trnio-12-2021-201

Аннотация

В статье автор рассматривает правовую природу транснациональных корпораций как субъектов международного частного права. Проводится анализ действующего законодательства. Делается вывод, что под транснациональной корпорацией понимается международно-оперирующая фирма в двух или более странах и управляющая этими подразделениями из одного или нескольких центров. Транснациональная корпорация выступает сложным субъектом в виду своей структуры. В статье уделяется внимание рассмотрению вопросов об определении правосубъектности транснациональных корпораций, рассмотрению объема актов, регламентирующих деятельность транснациональных компаний.

Ключевые слова: транснациональная корпорация, субъект международного частного права, правосубъектность транснациональных корпораций, правовой статус транснациональной корпорации.

\section{Abstract}

In the article, the author examines the legal nature of transnational corporations as subjects of private international law. The analysis of the current legislation is carried out. It is concluded that a transnational corporation is understood as an internationally operating firm in two or more countries and managing these divisions from one or more centers. A transnational corporation acts as a complex entity in view of its structure. The article focuses on the issues of determining the legal personality of transnational corporations, considering the scope of acts regulating the activities of transnational companies.

Keywords: transnational corporation, subject of private international law, legal personality of transnational corporations, legal status of a transnational corporation.

Транснациональные корпорации являются изучением специалистов из различных сфер науки в том числе и права. Актуальность исследования данного объекта можно объяснить повышением его экономической роли в системах мировой экономики. причинами повышенного интереса можно назвать увеличение капитала у таких объектов, повышение уровня конкуренции и барьеров входа в различные рынки. Их влияние распространяется также на правоотношения в сфере осуществления труда. Данные факторы обуславливают необходимость в совершенствовании старых и создании новых правовых механизмов регулирования деятельности транснациональных корпораций. 
В юридической науке вызывают споры вопрос об определении правового статуса транснациональных корпораций (ТНК), исследовании их как субъектов международного частного права.

Понимать под ТНК единое юридическое лицо не представляется возможным. ТНК необходимо рассматривать, учитывая и экономический, так и юридический аспект. Так, с точки зрения экономики, ТНК - хозяйственный комплекс, субъект, обладающий определенной экономической стратегией, а с юридической точки зрения ТНК представляет собой объединение юридических лиц, относительной чертой которого является то, что ответственность за нарушения норм права несет не ТНК целиком, а отдельные виновные в неправомерном поведении юридические лица.

Такая категория как "транснациональная корпорация" является результатом рассмотрения ООН вопросов о регулировании деятельности монополий международного уровня. Так, ООН даёт следующее определение данной категории: "транснациональная корпорация (корпорация) - это международно-оперирующая фирма в двух или более странах и управляющая этими подразделениями из одного или нескольких центров". Здесь следует понимать организации из различного рода производственных сфер, осуществляющие свою деятельность на территории двух или более государствах.

В науке рассматриваются различные способы определения категории ТНК. М. М. Богуславский определяет, что несмотря на юридическую множественность ТНК представляет выраженное экономическое единство. Особенности ТНК проявляются и в иных аспектах деятельности по сравнению со стандартными юридическими лицами. Так, в сферах административно-хозяйственного управления головное предприятия разрабатывает планы деятельности представителей ТНК в иностранном государстве, либо же происходит принятие совместных решений всеми самостоятельными участниками ТНК.

При рассмотрении вопроса об определении ТНК необходимо понимать главную его черту, а именно то, что оно представляется многонациональным предприятием, которое обладает экономическими единством при юридической множественности. такая форма организации зачастую бывает выгодно главному управлению транснациональные корпорации.

Состав ТНК можно определить в двух вариантах: 1) главная организация и подчиняющиеся ей организации; 2) равенство всех участников ТНК.

Однако при этом следует учитывать, что они одновременно зависимы друг от друга и одновременно обособленные друг от друга, при осуществлении попыток регулирования необходимо учитывать различие между регулированием нормами права и фактическим экономическим интересам ТНК.

ТНК присуще внешнее управление, то есть материнская компания решает вопрос об организационных вопросах осуществления деятельности, в то время как ответственность понесут только лишь подконтрольные ей организации.

Остаются неразрешенными дискуссии о содержании правосубъектности ТНК в связи с развитием глобальных экономических процессов. Это можно объяснить тем, что ТНК обладают своим экономическим планированием и обладают своей стратегией.

Согласно концепции национального законодательства РФ, отношения между государствами и компаниями носят гражданско-правовой характер. Определение правосубъектности ТНК является достаточно дискуссионным вопросом в науке, принято выделять две позиции правосубъектности ТНК:

1) признать за ТНК правосубъектность;

2) не признавать за ТНК правосубъектность, так как все члены ТНК обладают правосубъектностью, а наделение ТНК правосубъектностью может привести к излишнему расширению их полномочия, возможному приближению ТНК к статусу государства, несмотря на то что у ТНК отсутствуют многие признаки присущие государствам. 
Зачастую при определении ТНК ученые акцентируют внимание на том, что она обладает групповой правосубъектностью.

Рассматривая современное положение ТНК, можно прийти к выводу, что они оказывают если не определяющее воздействие, то безусловно оказывают непосредственное влияние на регулирование и формированию условия действующей экономической системы.

Традиционно принято рассматривать несколько уровней правового регулирования деятельности ТНК: внутреннее законодательство государств, двусторонние международные соглашения и многосторонние международные соглашения.

1) Национальное законодательство оказывает непосредственное влияние на все органы, филиалы ТНК, которые находятся на территории соответствующего государства. К данному виду законодательства в большинстве случаев следует относить законодательства об инвестиционной деятельности. В данных нормативных актах регулируется положение физических и юридических лиц которые занимаются непосредственно инвестированием в различного вида деятельности, но также следует понимать, что внутреннее законодательство опосредованно может влиять на всю деятельность ТНК, так это может проявляться при регулировании деятельности головного предприятия по отношению к подчиненным предприятиям и организациям, где опосредованно будут исполняться нормы страны, где находится главная организация. Но с другой стороны имеет место быть проблема неспособности национальных институтов государства регулировать деятельность ТНК.

2) Разного уровня инвестиционные соглашения, заключаемые государствами, заинтересованными в привлечении иностранного капитала для развития экономики, рынка труда. Анализируя современное регулирование, можно прийти к выводу, что центральную группу актов, регулирующих деятельность ТНК, представляют соглашение между страной базирования ТНК, то есть головной организации, и страной, где планируется инвестиционные иная хозяйственная деятельность.

3) Многосторонний международно-правовые договоры следует рассматривать как третью группу актов, регулирующих правовое положение ТНК. Их можно дифференцировать как региональные, субрегиональные и универсальные.

ЕС и ООН не раз пытались регламентировать деятельность транснациональных корпораций. В ООН были попытки создать единый свод норм устанавливающий правовой режим юридических лиц с разветвленной сетью филиалов. В данном кодексе рассматривались вопросы социального и экономического характера, устанавливались фактические права ТНК. В большинстве подобного рода договоров и соглашений отсутствуют санкции за нарушение содержащихся в нем норм и, как следствие, не прописан международный механизм их применения, что придает указанным нормам рекомендательный характер.

В ЕС разрешались вопросы осуществления корпораций деятельности в пределах стран участниц ЕС. В данных документах правосубъектность ТНК не затрагивалась.

Рассматривая правовое регламентирование ТНК в РФ можно выделить ряд проблем, например:

- д достаточно долгий и затратный процесс открытия новых предприятий на территории РФ;

жесткая политика государства в отношении стратегически важных направлений деятельности, интересах РФ. Так, например, согласно указа президента осуществление деятельности ТНК в сфере разработки ресурсов на Дальнем Востоке и Арктики является угрозой национальной безопасности; 
- несовершенство организационного и правового механизма устанавливающих образование, а также осуществление деятельности ТНК на отечественном рынке и иные проблемы.

Но одновременно с этим РФ заинтересована в привлечении инвестиций на отечественный рынок поэтому соответственно совершенствует регулирование инвестиционной деятельности.

На основании вышеизложенного можно сделать вывод, что определение правового режима ТНК является не разрешенным. Отсутствует регламентация деятельности и поведения ТНК при оказании влияния на экономики, конкуренцию, рынки. При определении правосубъектности ТНК необходимо понимать, что правосубъектность присуща самостоятельным участникам корпорации.

$$
* * *
$$

1. Об утверждении Основ государственной пограничной политики Российской Федерации: указ Президента РФ от 25.04.2018 г. № 174 // СЗ РФ. - 2018. - № 18. - ст. 2614.

2. Абраменкова А.А., Липницкий Т.В. Роль транснациональных корпораций в развитии мирового сельского хозяйства // Наука, бизнес, власть - триада регионального развития: сборник статей IV международной научно-практической конференции 2019. С. 13-17.

3. Асанова Л.Р. ТНК как субъект международного частного права // Аллея науки. 2019. № 1. С. $703-705$.

4. Богуславский М.М. Международное частное право. - М.: Юрист, 2002. 462c.

5. Карпович О.Г. Регулирование международной деятельности современных транснациональных корпораций // Право и политика. - 2017. № 1. С. 47 - 58.

6. Nukusheva A., Ilyassova G., Kudryavtseva L., Popova L., Shayakhmetova Z., Jantassova A. Transnational corporations in private international law: Do kazakhstan and russia have the potential to take the lead? // Entrepreneurship and Sustainability Issues. 2020. T. 8. № 1. C. 496-512.

7. Кудрявцева Л.В., Пулин Д.В. Правовое положение транснациональных корпораций в международном частном праве // Глобальный конституционализм и перспективы мирового развития. Москва. 2021. С. 79-84.

8. Кудрявцева Л.В., Саркисян Д.С. Корпорации в международном частном праве // Аграрное и земельное право. 2020. № 10 (190). С. 72-75.

\section{Ялмаев Р.А. \\ Роль взаимодействия как разновидности взаимоотношений государственной власти и местного самоуправления}

Чеченский государственный университет им. А.А. Кадырова

(Россия, Грозньй)

doi: 10.18411/trnio-12-2021-202

\section{Аннотация}

В статье проведено исследование современной модели взаимодействия органов государственной власти и местного самоуправления в России. По итогам исследования автор приходит к выводу, что среди взаимоотношений муниципальных и государственных властей преобладают отношения, построенные на принципе субординации. На основе разных степеней равноправных взаимоотношений различных субъектов, автор подразделяет данные отношения на три основные категории.

Ключевые слова: взаимодействие органов государственной власти и органов местного самоуправления, субординация.

\section{Abstract}

The article studies the modern model of interaction between public authorities and local selfgovernment in Russia. According to the results of the study, the author comes to the conclusion that relations based on the principle of subordination prevail among the relations between municipal and state authorities. On the basis of different degrees of equal relations between different subjects, the author divides these relations into three main categories.

Keywords: interaction of state authorities and local self-government bodies, subordination. 